\title{
Climate-Smart Bananas
}

\begin{abstract}
Some 130 countries grow bananas, with the 120 million tonnes they produce each year mainly being grown by smallholders for home consumption or sale at local markets. Around 800,000 tonnes are imported to the UK each year with each banana having a carbon footprint of 100-200 grams. We waste over a million bananas a day in Britain, at a cost to the climate of over 30,000 tonnes of emissions annually. Disease is the number one threat as almost all our bananas come from a single variety called Cavendish. A fungal disease called Topical Race 4 is already destroying large numbers of banana plants around the world. Storm damage, floods and drought likewise pose an increasing risk. Boosting plant health through good water and nutrient management can help to give resilience to climate change and disease threats alike. Organic production and the use of biological pest control are also proving successful.
\end{abstract}

Keywords Agroforestry $\bullet$ Banana-coffee $\bullet$ Hurricanes $\bullet$ Dominican Republic • Organic food $\bullet$ Tropical Race $4 \bullet$ Cavendish banana $\bullet$ Fusarium $\bullet$ Panama disease $\bullet$ Black Sigatoka

Once so rare in the West they were considered an exotic fancy, the banana is now a staple part of the daily menu for millions. Whether you like yours greenish and firm, spotty and sweet, or mostly black and super-soft, the different ripening stages of the bananas in our fruit bowls belie the almost 
complete lack of genetic diversity in the global banana crop itself. Bananas were first domesticated several thousand years ago in Southeast Asia, with the ancestors of the bananas we eat today growing wild in Papua New Guinea and Indonesia. By the time the first commercial shipment of refrigerated bananas reached Britain in 1902 [1], they were being grown in tropical and subtropical regions all around the world.

Banana plants like warm and wet conditions, along with fertile soils. They grow best in the tropics, with an average temperature in the high20s Celsius, and can be found in plantations in a wide band between 30 degrees north and south of the equator. Commercial plants are usually grown to just a few metres tall and are replanted every six years or so using the bulbous shallow-rooted rhizomes (called corms) that the adult plants produce [2]. Today some 130 countries grow bananas, with the 120 million tonnes they produce each year mainly being grown by smallholders for home consumption or sale at local markets. Bananas have become one of the most important crops in the world and are a vital part of human diets in many regions - the inhabitants of New Guinea are estimated to consume an impressive 200 kilograms of bananas per year each (in Europe and North America we average a relatively paltry 15 kilograms per person). Globally, it is India and China that dominate world supplies, along with high production in Central and South America [3] (Fig. 7.1).

Across the scores of nations and myriad plantations that grow bananas there are many hundreds of 'cultivars' too-selectively bred varieties that have a wide array of shapes, colours, size and tastes. These cultivars include the sweet, yellow-skinned inhabitants of our Western lunch boxes and the more starchy plantains widely used for cooking. They are wonder fruits in terms of the nutritional punch they pack, being rich in potassium as well as in vitamins $\mathrm{A}$ and $\mathrm{C}[5]$.

Almost all are descended from just two wild species and this lack of underlying genetic diversity is a serious risk factor when it comes to disease. In the lean post-war years of the 1950s bananas gradually began to return to the ration-hit grocery shelves. Then disaster overtook the world's banana growers, in the form of a fungus. The most popular variety at the time was Gros Michel (Big Mike) and one plantation after the next succumbed as a Fusarium fungus causing so-called Panama Disease ran rampant. This fungus attacks roots and eventually kills the whole plant. Its post-war outbreak cost over $\$ 2$ billion [6]. With no effective treatment, farmers were forced to switch to the more resistant variety-Cavendishthat we mainly eat today. The fungus didn't disappear though. In the early 


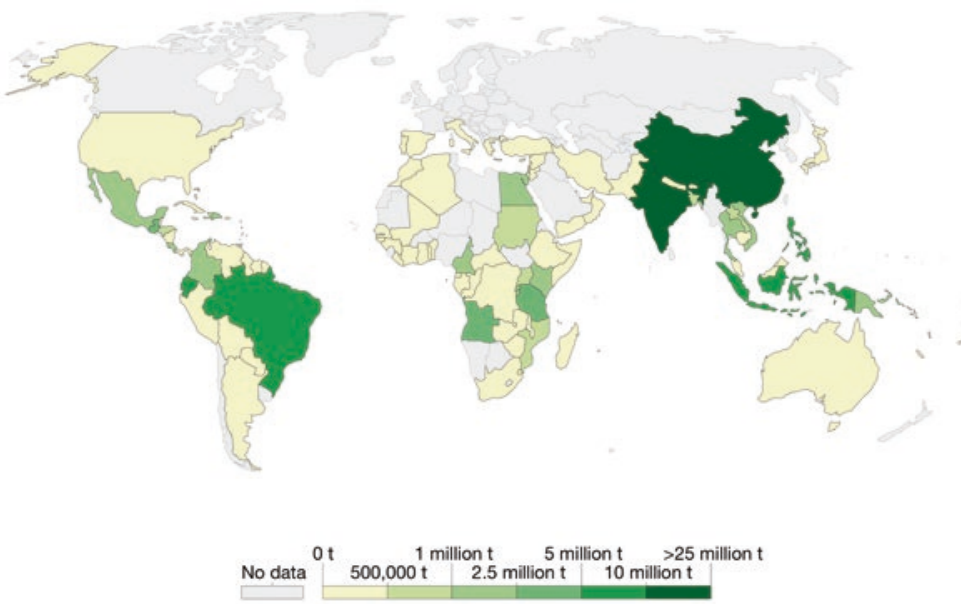

Fig. 7.1 Global banana production in 2014 by country of origin (Source: Hannah Ritchie, Our World in Data) [4]. Available at: https://ourworldindata. org/grapher/banana-production

1990s a new strain of it called Tropical Race 4 emerged that could attack the Cavendish banana plants too. Tropical Race 4 has already spread across Southeast Asia and into East Africa and the Middle East. It can wipe out whole plantations and as yet no resistant banana variety that can easily replace the under-siege Cavendish has been found [7]. Adding fuel to the banana disease fire comes climate change. Through direct impacts like storms, drought and heat, to indirect threats like accelerating disease spread, it is an unwelcome complication for growers already facing a highly uncertain future.

Our own break time banana here in Scotland originated in the balmier climes of the Dominican Republic - a sweet-spot on the global growing map and currently the world's biggest supplier of organic bananas [8]. Produced by the thousand or so farmers on the island, almost all of the banana exports from the Dominican Republic end up in Europe.

Along with the rest of the roughly 800,000 tonnes of bananas imported to the UK each year, my own banana has travelled a very long distance, has 
been refrigerated along the way, and so carries with it a substantial carbon footprint. However, as far as bananas go, it is relatively low carbon. The average kilogram of bananas results in the emission of $0.5-1.3$ kilograms of greenhouse gas - or 100-200 grams per banana.

In the tropical plantations, use of nitrogen fertilisers (causing emissions of nitrous oxide from the soil) and the energy used (for machinery and to make fertilisers and pesticides), are the main sources of on-farm emissions. More are racked up in harvesting, processing (fungicide sprays and chlorine dips to remove the sticky latex that oozes from cut stems), and packaging. For most bananas that end up on distant foreign shores it is then transport that adds a big extra dollop of carbon [9].

The journey from plantation to port tends to be short and by diesel truck. The bananas are then loaded onto refrigerated ships-called reefers-or container ships at coastal towns like Manzanillo to begin their two-week journey across nearly 4,000 miles of ocean. These ships are powered by heavy fuel oil, and if the ships are inefficient and don't have a cargo to carry on the return trip, their emissions can account for up to two-thirds of the total banana footprint [10]. Once imported, the boxes of bananas are taken to regional centres for ripening and then distribution to shops and supermarkets. Once we buy them, a final race against time to avoid an even larger climate penalty begins.

Few banana lovers have avoided the pain of a seemingly hard and green bunch one day becoming blackened mush the next. There is the slimy horror of a forgotten banana in the bottom of a school bag or the pungent surprise of a benthic banana layer in the fruit bowl.

Keeping bananas wrapped and the bunches separated can apparently slow how fast they ripen-ripe bananas emit ethylene gas which will accelerate ripening in any nearby bananas if they aren't protected. Refrigeration can prolong their lifespan but, as has caused plenty of arguments in our house, everything else in the fridge risks taking on a banana-ey taste.

Having travelled a long way and already with a weighty carbon footprint, the wastage of bananas by consumers contributes a major part to their life-cycle climate change impact. It also represents the prime target for most of us to reduce it. Avoidable wastage (so not including the banana skins) in the UK alone tops 65,000 tonnes a year-over a million bananas every day [11]. Most of this is simply through them not being used in time and means 30,000-65,000 tonnes of unnecessary greenhouse gas is emitted annually. Each banana we save from the bin-by keeping an eye on their ripeness and avoiding overbuying-helps to avoid the growing, 
processing and transport required to deliver its replacement. All those parts of the banana's life cycle can be targeted directly too.

On the farm, a reduction in fertiliser and pesticide use-as achieved with our own organic bananas in the Dominican Republic-means a smaller footprint compared to their conventionally produced cousins [12]. For transport over land, lower driving speeds, alternative fuels and improved logistics can lower emissions, while in the ripening and distribution centres more energy efficient air-conditioning and leak-free refrigeration will cut both costs and carbon. For the biggest part of banana's carbon footprint - shipping - a switch away from traditional reefer ships to larger, more efficient, refrigerated container ships can slice over a third off transport emissions. Coupled with lower cruising speeds, computercontrolled storage, and low-carbon fuels and refrigerants, addressing shipping emissions is a prime target [9]. Globally, shipping now accounts for 2 per cent of all greenhouse gas emissions and pressure is mounting on the wider industry to curtail its use of fossil fuels [13].

With a global banana industry under siege from disease, and climate change adding an unwelcome risk to the mix, climate-smart approaches have become more important than ever [14]. Banana plants like it warm and wet, and some plantations are already on the margins of the viable climate envelope. As each crop cycle takes 12 months or more, they are also exposed to the full year's worth of extreme weather events. Drought is the climate risk that most commonly concerns banana growers [15]. Rainy seasons are set to become less reliable and farmers in the drier subtropical zones face a damaging combination of reduced rainfall and high temperatures. By the 2050 s, climate change-mainly via drought impactsis expected to have wiped over a million square kilometres off the viable banana-growing map in the sub-tropics [16]. In the second half of the century extreme temperatures are also predicted to take a toll, with plantations in some areas of Argentina and India having to endure temperatures in excess of 40 degrees Celsius through the summer season. However, this shifting climate envelope for bananas should mean a major boost in production in some parts of the tropics, and a northwards extension of the growing range in Europe, Asia and North America. Over 5 million square kilometres is expected to shift out of the too-cold-for-bananas climate zone by 2070 and, overall, the global growing area for bananas is expected to increase due to climate change in the twenty-first century. 
Our growers in the Dominican Republic can expect a mixed bag of long-term climate impacts. The news on temperature looks okay, with a predicted rise of 2 to 3 degrees Celsius by the 2070s [17], meaning new summer highs of up to 30 degrees Celsius and warmer winter minimums of 20 degrees Celsius. The banana plants should, therefore, still have a comfortable growing temperature throughout the year. Rainfall is more of a concern. As climate change intensifies so the amount of wet season rain in the Dominican Republic is set to fall and the dry season to extend [16]. Without irrigation this may raise the spectre of drought risks in the long term, but for the farmers of the Dominican Republic there's already a major weather threat to contend with: hurricanes.

The Atlantic hurricane season of 2017 was devastating. It encompassed 17 named storms of which Hurricanes Harvey, Maria and Irma were the most violent. Tropical storm Maria emerged on the 16th of September and was to be the deadliest storm of them all. Picking up energy over an especially warm ocean, the storm grew rapidly, and by the 18th of September it had become a Category 5 . As it raged across the Caribbean it claimed the lives of over 140 people and left a trail of destroyed homes, infrastructure and livelihoods.

Maria passed to the north and east of the Dominican Republic on the 21 st of September 2017, bringing damaging high winds and depositing huge amounts of rain in just a few hours. Around 5,000 hectares of banana plantations were flooded. Earlier high winds during storm Irma had already bent and broken many banana plants, now, with waterlogged soils too, many plants suffered irreparable damage [18]. Some growers saw 80 per cent of their plantations destroyed in that ferocious 2017 storm season, the wet conditions and damaged plants proving a ripe breeding ground for fungal diseases too [19].

Whether climate change will alter storm and hurricane risks in the Dominican Republic, and more widely, is still uncertain. Warmer seas have the potential to increase the energy of storms and result in more powerful hurricanes, but changing wind shear (the difference in speed and direction of winds in the upper and lower levels of the atmosphere) may actually reduce their number [20]. Whatever the net effect of these two opposing forces, it is likely that the kind of extreme rainfall and flooding risks posed by the storm season of 2017 will be even greater in the coming decades. 
The huge importance of bananas to the livelihoods of so many people around the world has already spurred climate-smart action. Improved knowledge and access to training has been central to these efforts. In Costa Rica, for instance, the banana industry supports over 100 thousand families [21] and a joint effort by the government and development agencies has now produced practical guidance for growers and suppliers. Its aim is to embed greater climate resilience while simultaneously boosting production and cutting emissions [14]. Likewise, the large banana industries in Ecuador [22] and the Dominican Republic are benefiting from increased research and sharing of good practice, with the Dominican Republic seeing more and more assessment of how its organic production methods could help deliver greater protection from drought and pest risks [8].

Water is a concern for many growers. Keeping their thirsty plants wellwatered throughout the year often requires the use of irrigation, but changing rainfall patterns, and increasingly unreliable supplies from glacial melt in areas like Ecuador, mean improved water management is a central part of the climate-smart response. The use of drip irrigation methods [23] and more rainwater collection and storage [24] can help buffer the effects of drought. If used alongside good weather forecast information and crop water demand advice, the water supply can be much better matched to the needs of the plant. As banana plants have shallow roots, mulching their soils with clippings or planting with low-growing cover crops can also provide a shaded understory that helps to maintain soil moisture even when temperatures soar [9]. Such mulching and use of cover crops has the added benefits of suppressing weeds, reducing soil erosion, and cutting run-off of pesticides and herbicides during times of very heavy rainfall [25].

With disease resistance being the urgent focus of most banana-breeding programmes around the world, research on more drought-resistant plants has so far been limited. Some varieties do show more drought tolerant traits though and, for those farmers facing the biggest drought risks or having the least ability to adapt through irrigation, development and supply of new hybrids able to withstand drier conditions could be vital [5].

Like too little water, too much water can also pose a serious risk for bananas in the form of disease. Here, fungal diseases like the dreaded Black Sigatoka become a real threat [26]. Since 2008 this devastating fungus has spread through all the main banana-producing areas of the Caribbean-in Guyana it annihilated banana production in just three years 
[27]. Black Sigatoka thrives in wet, warm conditions, with heavy rainstorms and flooding allowing it multiply and spread quickly. Though fungicide treatment can help control it, these fungicides are expensive. Using expert advice and support, many farmers have now responded by boosting overall plant health and disease resilience through better fertiliser use, removal of infected plants, and improved soil drainage [28]. Careful timing and application of the expensive fungicides has also allowed more farmers to use them, with the added bonus of reducing water pollution risks during heavy rain. Production in Guyana is already recovering, and a region-wide strategy is now planned where best practice is shared across all nations. This plan includes providing disease-free rhizomes to growers, developing new disease-resistant varieties, and building public awareness and the capacity to respond to future outbreaks [27].

For the powerful storms and hurricanes that threaten the Caribbean each year, early warning systems and recovery plans may help save bananas as well as many lives. The banana plants themselves grow from a large rhizome, so even if a storm damages leaves and stems they can often regenerate if given the chance. Where wind damage destroys large numbers of plants, as can happen with hurricanes, having robust systems for recovery in place-like rapid infrastructure repair, disease-free rhizome and equipment re-supply-can help limit the overall impacts and get production up and running quickly [29].

In the face of more extreme weather, and with diseases like fusarium wilt and Black Sigatoka threatening to wipe out their livelihoods, many banana growers are turning to diversification-planting other crops alongside their bananas - as a way to give more resilience. One of the most successful of these banana-growing marriages is with coffee.

Coffee grows in similar conditions to bananas and is itself at major risk from climate change impacts, such as through higher temperatures. Growing it alongside bananas means the banana leaves provide muchneeded shade during the hottest parts of the day and often means a more consistent coffee crop. The residues from the banana plants also provide a useful mulch for the coffee plants, helping to boost fertility and carbon storage in the soils, retain soil moisture and supress weeds. This winning combination provides a valuable insurance policy for farmers in the event of disease attack and loss of one of the crops.

The nutrient and water needs of the two crops do have to be well balanced-there is a risk that the coffee will outcompete the banana plants if 
both aren't supplied with enough fertiliser and water, or that planting the bananas too close together will shade the coffee too much. Such bananacoffee intercropping strategies have been known about for decades and have already been successful on farms across Latin America, Africa and Asia [30]. Research on banana-coffee combinations in Uganda has reported increases in yield values and farmer income of over 50 per cent, alongside improved coffee quality, resilience to extreme weather, and more carbon storage in the plants and the soils beneath them.

For banana growers around the world, climate change represents a real risk multiplier for the major threats already posed by disease and severe weather events. Climate-smart approaches, local capacity-building, and enhanced regional systems that allow sharing of best practice and support can all help ensure a banana-shaped future of our break time.

\section{REFERENCES}

1. Mckie, R. We're all going bananas. The Observer. https://www.theguardian. com/observer/focus/story/0,6903,746576,00.html. (2002).

2. FAO. Banana. http://www.fao.org/land-water/databases-and-software/ crop-information/banana/en/ (2018).

3. FAO. Banana Facts and Figures. Food and Agriculture Organization of the United Nations. http://www.fao.org/economic/est/est-commodities/ bananas/bananafacts/en/\#.XOqq0y2ZPUo (2018).

4. Ritchie, H. Global banana production, 2014. Ourworldindata.org. https:// ourworldindata.org/grapher/banana-production (2018).

5. Ravi, I., Uma, S., Vaganan, M. M. \& Mustaffa, M. M. Phenotyping bananas for drought resistance. Front. Physiol. 4, 9 (2013).

6. Fusariumwilt.org. Panama Disease. https://fusariumwilt.org/index.php/en/ about-fusarium-wilt/ (2018).

7. FAO. Banana Fusarium Wilt Disease. http://www.fao.org/food-chain-crisis/how-we-work/plant-protection/banana-fusarium-wilt/en/ (2018).

8. FAO. Organic Banana Production in the Dominican Republic. Food and Agriculture Organization of the United Nations. http://www.fao.org/worldbanana-forum/projects/good-practices/organic-production-dominicanrepublic/en/\#.XOqrCC2ZPUo (2018).

9. FAO. Carbon Footprint of the Banana Supply Chain. Food and Agriculture Organization of the United Nations. http://www.fao.org/3/a-i6842e.pdf (2017).

10. Iriarte, A., Almeida, M. G. \& Villalobos, P. Carbon footprint of premium quality export bananas: Case study in Ecuador, the world's largest exporter. Sci. Total Environ. 472, 1082-1088 (2014). 
11. WRAP. Household food and drink waste in the United Kingdom 2012. Waste and Resource Action Programme. http://www.wrap.org.uk/sites/files/wrap/ hhfdw-2012-main.pdf.pdf. (2013).

12. Roibás, L., Elbehri, A. \& Hospido, A. Carbon footprint along the Ecuadorian banana supply chain: Methodological improvements and calculation tool. J. Clean. Prod. 112, 2441-2451 (2016).

13. Gabbattis, J. Carbon emissions from global shipping to be halved by 2050 , says IMO. The Independent. https://www.independent.co.uk/environment/ ships-emissions-carbon-dioxide-pollution-shipping-imo-climatechange-a8303161.html (2018).

14. FAO. Reducing Carbon and Water Footprints in Banana Plantations. Food and Agriculture Organization of the United Nations. http://www.fao.org/ world-banana-forum/projects/reducing-carbon-and-water-footprints-inbanana-plantations/en/(2018).

15. Calberto, G., Blake, D., Staver, C., Carvajal, M. \& Brown, D. X International Symposium on Banana: ISHS-ProMusa Symposium on Agroecological Approaches to Promote Innovative Banana 1196 179-186.

16. Calberto, G., Staver, C. \& Siles, P. An assessment of global banana production and suitability under climate change scenarios. Climate Change and Food Systems: Global Assessments and Implications for Food Security and Trade (Food Agriculture Organization of the United Nations (FAO), Rome, 2015).

17. Carbonbrief. Mapped: How every part of the world has warmed-And could continue to warm. Carbonbrief.org. https://www.carbonbrief.org/mappedhow-every-part-of-the-world-has-warmed-and-could-continue-to-warm (2018).

18. producebusinessuk.com. A Quarter of Farms Flooded for Major Banana Exporter. https://www.producebusinessuk.com/supply/stories/2017/ 09/27/a-quarter-of-farms-flooded-for-major-banana-exporter (2017).

19. freshplaza.com. Dominican Republic: "We Have Losses of up to 50 Percent". https://www.freshplaza.com/article/185965/Dominican-Republic-Wehave-losses-of-up-to-50-percent/ (2017).

20. GFDL. Large-scale Climate Projections and Hurricanes. Geophysical Fluid Dynamics Laboratory, NOAA, USA. https://www.gfdl.noaa.gov/globalwarming-and-21st-century-hurricanes / (2018).

21. Alvarado, L. Costa Rica leads the way in carbon neutral banana production. Costa Rica Star. https://news.co.cr/carbon-neutral-banana-productioncosta-rica/70539/(2018).

22. Elbehri, A. et al. Ecuador's Banana Sector Under Climate Change. Food and Agriculture Organization of the United Nations. http://www.fao.org/3/ai5697e.pdf (2016).

23. Silva, A. J. P. d., Coelho, E. F., Miranda, J. H. d. \& Workman, S. R. Estimating water application efficiency for drip irrigation emitter patterns on banana. Pesq. Agropec. Bras. 44, 730-737 (2009). 
24. FAO. Feasibility Study of Rainwater Harvesting for Agriculture in the Caribbean Subregion. Food and Agriculture Organization of the United Nations. http://www.fao.org/3/a-bq747e.pdf (2014).

25. Bellamy, A. S. Banana production systems: Identification of alternative systems for more sustainable production. Ambio 42, 334-343 (2013).

26. freshfruitportal.com. Black Sigatoka Fungus Hits Dominican Republic's Bananas. https://www.freshfruitportal.com/news/2011/11/21/blacksigatoka-fungus-hits-dominican-republics-bananas/ (2011).

27. FAO. Battling Black Sigatoka Disease in the Banana Industry. Food and Agriculture Organization of the United Nations. http://www.fao.org/3/aas087e.pdf (2013).

28. Ploetz, R. Black Sigatoka of banana: The most important disease of a most important fruit. APS Feat 2, 126. https://doi.org/10.1094/PHI-I-20010126-02 (2001).

29. FAO. Post Disaster Damage, Loss and Needs Assessment in Agriculture. Food and Agriculture Organization of the United Nations. http://www.fao.org/ docrep/015/an544e/an544e00.pdf (2012).

30. Asten, P. V. et al. Coffee-Banana Intercropping: Implementation Guidance for Policymakers and Investors. Global Alliance for Climate-Smart Agriculture. https://cgspace.cgiar.org/bitstream/handle/10568/69017/ CCAFSpbCoffee-Banana.pdf (2015).

Open Access This chapter is licensed under the terms of the Creative Commons Attribution 4.0 International License (http://creativecommons.org/licenses/ by $/ 4.0 /$ ), which permits use, sharing, adaptation, distribution and reproduction in any medium or format, as long as you give appropriate credit to the original author(s) and the source, provide a link to the Creative Commons licence and indicate if changes were made.

The images or other third party material in this chapter are included in the chapter's Creative Commons licence, unless indicated otherwise in a credit line to the material. If material is not included in the chapter's Creative Commons licence and your intended use is not permitted by statutory regulation or exceeds the permitted use, you will need to obtain permission directly from the copyright holder.

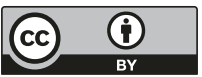

